\title{
Seasonal Incidence of Guillain-Barre Syndrome in Rumah Sakit Islam Jemursari Surabaya
}

\author{
S Syifak ${ }^{1}$ and D Yuniati ${ }^{1}$ \\ ${ }^{1}$ Neurology department, Faculty of Medicine Universitas Nahdlatul Ulama Surabaya, Jemursari 51-57 Surabaya, East Java, \\ Indonesia \\ *Corresponding author Email: s.syifak@unusa.ac.id
}

\begin{abstract}
Guillain Barre Syndrome (GBS) is the leading cause of acute flaccid paralysis. Former study showed the highest GBS incidence, particularly in April-May, during seasonal transition from rainy to summer period. Indonesia has only limited study about demographic profile of GBS incidence. Rumah Sakit Islam Jemur Sari (RSI JS) Surabaya is the only type B hospital in Wonocolo, a district of Surabaya. Mapping the incidence of GBS regionally and temporally could assist the strategic planning of diagnosis and treatment for the disease. This descriptive study was conducted in cross sectional design, using medical record of all patient with GBS in emergency room (ER) and ward of RSI JS Surabaya from Januari 2017-November 2019. The inclusion criteria was all the patient with GBS (diagnosed by Neurologist or Medical Doctor), and the exclusion criteria were a history of GBS, hyperglicemia, and hypokalemia. The total of medical record was 25 , male $60 \%$ (15) and female $40 \%$ (10). Range of patient's age was 10-55 years, the highest incidence were 10-20 years (24\%, 6 patients) and 40-50 years (24\%). The peak of incidence for 3 years was consistent in January (7 cases, 28\%) and March (28\%). Weakness was the main complain of most patient $(80 \%)$. Based on three years of observation in our study, GBS is more common in the first transition season (March-May) that any other seasons.
\end{abstract}

Keyword: GBS, incidence, Surabaya

\section{INTRODUCTION}

Guillain-Barre Syndrome (GBS) is the leading cause of acute flaccid paralysis in the world after the eradication of polio [1]. A study in Bandung showed the ratio of 3:1 for male:female, and the mean of age was 23,5 year. The highest incidence was on AprilMay, a period of transition season when rainy changes into summer [2]. The definition of transition season based on Kamus Besar Bahasa Indonesia $(\mathrm{KBBI})$ is a transition season (marked by erratic air condition, powerful wind) or a transition period from summer to rainy season [3].

GBS annually incident is 1-2 case in every 100.000 people [4]. A study at Rumah Sakit Umum Pusat Nasional Cipto Mangunkusumo (RSCM) Jakarta showed 7,6 new case/year [1]. A metaanalysis in Oxford showed that the risk of GBS escalated $14 \%$ in winter than summer [5]. A study in India showed the escalation of GBS incidence in summer than spring [6]. Indonesia has only limited study about demographic profile of GBS incidence based on seasonal variation.

Rumah Sakit Islam Jemursari (RSI JS) Surabaya is the only type B hospital in Wonocolo, a district of Surabaya [7]. Mapping the incidence of GBS regionally and temporally could assist the strategic planning of diagnosis and treatment for the disease.

\subsection{Definition and Epidemiology}

GBS is an acute polyneuropathy caused by autoimmune reaction to peripheral nerves. GBS is marked by acute lower motor neuron (LMN) paralysis and albuminocytological dissociation of cerebrospinal liquor [1]. Before GBS manifests clinically, a history of upper respiratory tract infection, gastrointestinal tract infection, or febrile of unknown origin usually described by patient [4].

\subsection{Pathophysiology}

Molecular mimicry is the key to the pathophysiology of GBS. This mechanism of inflammatory neuropathy is caused by cross reactivity between neural antigen and antibody inducted by specific infections (in example: C. jejuni infection). Campylobacter jejuni expresses lipooligosaccharide to its outer membrane that mimics gangliosides and triggers the antigangliosides antibody to attack the nerves [8].

\subsection{Clinical Findings}

GBS evolves in days, started with hypoesthesia and weakness of the lower limbs. The distal muscles usually the first ones to develop weakness then the proximal, this characteristic differs from the polyradiculopathy type of weakness theory (proximal first then distal). Weakness of muscles are getting worse in days, and after two weeks usually 
the muscles gaining their strength back. About $66 \%$ patient complained neuropathic low back or thigh pain. Weakness of muscles for eye movement complained by $20 \%$ patient, $30 \%$ of patient needed intubation and ventilator. Autonomic disfunction in GBS can cause tachycardia, bradycardia, hypertension, hypotension, gastric hypomotility, and urinary retension. Autonomic failure can cause mortality [9].

Electromyography (EMG) is used to differs GBS from other diseasea. Nerve conduction study is specially useful to the diagnosis of GBS variant and prognosis. Another method to exclude the different diagnosis of GBS is lumbar puncture [8].

\subsection{Seasons in Indonesia}

Indonesia is an archipelago and tropical country, lays between Asia and Australia continent, between Pacific and Hindia ocean, and traversed by equator. Indonesia has a lot of strait and bay. These conditions make Indonesia prone to the season's changes. El Nino and La Nina storm is a phenomenon that influence Indonesia's climate, the other things that give influence are Dipole Mode, Asia-Australia Monsun Circulation, Inter Tropical Convergence Zone, and Sea Surface Temperature [10][11].

Badan Meteorologi, Klimatologi, dan Geofisika (BKMG/Indonesian Agency for Meteorological, Climatological and Geophysics) defines summer as a period of amount of monthly rainfall $<150 \mathrm{~mm}$, and rainy season is $>150 \mathrm{~mm}$. Between those two seasons, there are 2 period of transition season. Transition season marked by a pattern of rainfall in the day or night for 2-5 days, the intensity of rain is mild-moderate, accompanied by strong winds and thunderstorms, the wind blows from the south to the southeast. Based on BKMG data for 40 years, the first transition season is during March-May, and the second is September-November [2]. During transition season, weather, rainfall and humidity change inconsistently. These changes effect the ecology of infectious agents and host directly or indirectly, including human's immunity system [12].

\subsection{Immunity and Season}

Seasonal changing periodically influence all forms of life. In human's life, there are so many diseases influenced by specific season, for example the infectious disease [13]. Transition seasons also effect microbes, vectors, and animals in hostreservoirs interaction with bacteria or virus [12].

Strong winds and high humidity happens in transitional seasons, increase blood circulation to the skin that leads to peripheral vasoconstriction. On hormonal sides, adrenal gland will produce catecholamine that will make vasoconstriction furthermore. A continuous release of catecholamine leads to fatigue, this will decrease the production followed by the releasing of serotonin which has vasoconstriction, bronchoconstriction, and intestinal spasm effect. All these things caused the organs to become easily infected, marked by leukocytosis in seasonal changing. Changes in the composition of $\mathrm{T}$ and $\mathrm{B}$ lymphocytes during the transition season affect the incidence of infection and autoimmune diseases. IL-6 in blood level and CRP increase during the winter in Europe, these are biomarkers for the risk of autoimmune disease. Circadian rhythm and the decreased of vitamin D metabolism can reduce human immune and increase the risk of infectious and autoimmune diseases [14].

\subsection{Wonocolo, A District of Surabaya}

Surabaya consists of 31 districts, the total of Surabaya population is 2.484 .583 in 2002 . Wonocolo is one of districts in Surabaya, the total of its population was 63.185 in 2002 . Wonocolo is divided into 5 smaller districts (Sidosermo, Bendul Merisi, Margorejo, Jemur Wonosari, and Siwalankerto). Wonocolo has 1 public market, 3 pusat kesehatan masyarakat (state's first level of health service), and 1 type B hospital as secondary health service (RSI JS Surabaya) [15][16].

\section{MATERIALS AND METHODS}

This descriptive study was conducted in cross sectional design, using medical record of all patient with GBS in emergency room and ward of RSI JS Surabaya from Januari 2017-November 2019. The inclusion criteria was all the patient with GBS (diagnosed by Neurologist or Medical Doctor), and the exclusion criteria were a history of GBS, hyperglicemia, and hypokalemia.

\section{RESULTS}

The total of medical record was 25 , male $60 \%$ (15) and female $40 \%$ (10). Range of patient's age was 10 55 years, the highest incidence were 10-20 years (24\%, 6 patients) and $40-50$ years (24\%). The peak of incidence for 3 years was consistent in January ( 7 cases, 28\%) and March (28\%). Weakness was the main complain of most patient $(80 \%)$.

\section{DISCUSSION}

This study was conducted in cross sectional design to observe the seasonal incidence of GBS in transition or non-transition season at RSI JS Surabaya. The inclusion criteria was all the patient with GBS (diagnosed by Neurologist or Medical 
Doctor), and the exclusion criteria were a history of GBS, hyperglicemia, and hypokalemia. A total of 25 subject, $60 \%$ was male (15 patient) and $40 \%$ was female (10 patient). A study in Chile confirmed this founding, $59 \%$ of their subject was male, the ratio was 1.47:1 for male:female [17] and a study in Brazil $56,4 \%$ of their subject was male [18].

In our study, the frequency of incidence of GBS was especially in the second decade of life (age 1020,6 patient, 24\%) and fifth decade of life (age 40$50,24 \%$ ). A study in India for 328 subject resulted similar, the mean of age was 30 year and the highest frequency was at the second and fourth decade of life [19].

The association between GBS and seasonal variation was still debatable. An increased incidence of GBS at particular time may be associated with the high incidence of infection due to weather changes. But there was no strict boundary on climate change and weather patterns in several countries, including Indonesia, and that made the analysis of the association between seasons and GBS even more complex. A study by Webb concluded that there was an increase in the incidence of GBS during winter in European countries $(1,28: 1)$, while a study in Latin America the ratio was $0.75: 1$ for winter:summer.

A study in North China concluded that GBS especially AMAN (acute motor axonal neuropathy) type was associated with summer, possibly associated with the increasing of $\mathrm{C}$. jejuni infection at the time of the study. A study in Hong Kong concluded that there was no association between season and GBS incidence [17][20][21][22].

\begin{tabular}{|c|c|c|c|c|c|}
\hline \multicolumn{6}{|c|}{ TABEL 1 Characteristics of Subjects by Month of Submission } \\
\hline & & Frequency & Percent & Valid Percent & Cumulative Percent \\
\hline \multirow[t]{10}{*}{ Valid } & January & 7 & 28.0 & 28.0 & 28.0 \\
\hline & February & 2 & 8.0 & 8.0 & 36.0 \\
\hline & March & 7 & 28.0 & 28.0 & 64.0 \\
\hline & April & 4 & 16.0 & 16.0 & 80.0 \\
\hline & June & 1 & 4.0 & 4.0 & 84.0 \\
\hline & July & 1 & 4.0 & 4.0 & 88.0 \\
\hline & August & 1 & 4.0 & 4.0 & 92.0 \\
\hline & September & 1 & 4.0 & 4.0 & 96.0 \\
\hline & November & 1 & 4.0 & 4.0 & 100.0 \\
\hline & Total & 25 & 100.0 & 100.0 & \\
\hline
\end{tabular}

Our study found that the highest incidence of GBS in 2017 was on March-April. There were four patients submitted in March, two patients in April, and one patient in June. The first transition season was in March-April, the second was in OctoberNovember [23][24].

The highest incidence of GBS in 2018 was on February-April. There were two patients submitted in January, three patients in February, three patients in March, three patients in April, one patient in July, and one patient in August. The first transition season was in April-June, the second was in SeptemberNovember [25][26].

The highest incidence of GBS in 2019 was on January. There were two patients submitted in January, one patient in April, 1 patient in September, and one patient in November. The first transition season was in April-May, the second was in October-November [27][28].
Based on three years of observation in this study, GBS is more common in the first transition season (March-May) that any other seasons.

Our study was using secondary data, we couldn't find data for the adequate anamnesis, complete physical examinations, nutrition, etiology of infection, EMG or lumbar puncture, and the severity of neurological deficit. A prospective study would be necessary to make data valuable.

\section{CONCLUSION}

The conclusion that can be drawn from the research conducted is that weakness is the main complaint of the majority of patients $(80 \%)$. Based on three years of observations in our study, GBS was more common in the transition season (March-May) than other seasons. 


\section{REFERENCES}

[1] S. Harris, "Buku Ajar Neurologi FKUIRSCM : Cerebral Small Vessel Desease," Dep. Neurol. FKUI-RSCM, 2016, doi: 10.1016/j.scitotenv.2016.04.179.

[2] A. L. Bayong Tjasyono HK and S. W. B. H. Ina Juaeni, Ruminta, "Dampak Variasi Temperatur Samudera Pasifik Dan Hindia Ekuatorial Terhadap Curah Hujan," J. Sains Dirgant., 2008.

[3] Pusat Bahasa Kemdikbud, "Kamus Besar Bahasa Indonesia ( KBBI )," Kementeri. Pendidik. dan Budaya, 2016.

[4] J. Brust, Current Diagnosis \& Treatment Neurology, 3rd ed. 2019.

[5] A. B. Haghighi et al., "Seasonal variation of Guillain-Barré syndrome admission in a large tertiary referral center in Southern Iran: A 10 year analysis," Acta Neurol. Taiwan., 2012.

[6] T. Mathew, M. Srinivas, R. Nadig, R. Arumugam, and G. R. K. Sarma, "Seasonal and monthly trends in the occurrence of Guillain-Barre syndrome over a 5-year period: A tertiary care hospital-based study from South India," Annals of Indian Academy of Neurology. 2014, doi: 10.4103/0972-2327.132662.

[7] P. K. Surabaya, "No Title," 2017. http://dinkes.surabaya.go.id/portal/profil/dk k-dalam-angka/sarana-pelayanankesehatan/\%0A.

[8] P. D. Donofrio, "Guillain-Barré Syndrome," Contin. Lifelong Learn. Neurol., vol. 23, no. 5, pp. 1295-1309, Oct. 2017, doi: 10.1212/CON.0000000000000513.

[9] A. D. Walling and G. Dickson, "GuillainBarré syndrome.," Am. Fam. Physician, vol. 87, no. 3, pp. 191-7, Feb. 2013, [Online]. Available:

http://www.ncbi.nlm.nih.gov/pubmed/2341 8763.

[10] M. Ridwan, "Prakiraan Musim Kemarau 2017 di Indonesia," 2017. https://www.bmkg.go.id/iklim/prakiraanmusim.bmkg? $\mathrm{p}=$ prakiraan-musim-kemarau2017-di-indonesia\&tag=prakiraanmusim\&lang=ID.

[11] M. Ridwan, "Prakiraan Musim Hujan 2017 di Indonesia," 2017.

https://www.bmkg.go.id/iklim/prakiraanmusim.bmkg?p=prakiraan-musim-hujan2017-di-indonesia\&tag=prakiraanmusim\&lang=ID.

[12] L. Geller, "Under the Weather: Climate, Ecosystems, and Infectious Disease," Emerg. Infect. Dis., vol. 7, no. 7, pp. 606608, Jun. 2001, doi: 10.3201/eid0707.017750.

[13] J. A. Patz, D. Engelberg, and J. Last, "The Effects of Changing Weather on Public Health," Annu. Rev. Public Health, vol. 21, no. 1, pp. 271-307, May 2000, doi: 10.1146/annurev.publhealth.21.1.271.

[14] I. R. Marjianto, "Hubungan Antara Musim Pancaroba dengan Derajat Keparahan Guillain-Barre Syndrome,” 2017, [Online]. Available:

http://repository.unair.ac.id/61816/.

[15] "Profil Kota Surabaya Jawa Timur," 2003. http://ciptakarya.pu.go.id/profil/profil/barat/ jatim/surabaya.pdf (accessed Nov. 15, 2019).

[16] "Wonocolo, Surabaya." https://id.wikipedia.org/wiki/Wonocolo,_Su rabaya (accessed Nov. 15, 2019).

[17] G. Rivera-Lillo et al., "Incidence of Guillain-Barré syndrome in Chile: a population-based study," J. Peripher. Nerv. Syst., vol. 21, no. 4, pp. 339-344, Dec. 2016, doi: $10.1111 /$ jns. 12182 .

[18] M. E. Dourado, R. H. Félix, W. K. A. da Silva, J. W. Queiroz, and S. M. B. Jeronimo, "Clinical characteristics of Guillain-Barré syndrome in a tropical country: a Brazilian experience," Acta Neurol. Scand., vol. 125, no. 1, pp. 47-53, Jan. 2012, doi: 10.1111/j.1600-0404.2011.01503.x.

[19] J. Kalita, U. K. Misra, G. Goyal, and M. Das, "Guillain-Barré syndrome: subtypes and predictors of outcome from India," $J$. Peripher. Nerv. Syst., vol. 19, no. 1, pp. 3643, Mar. 2014, doi: 10.1111/jns5.12050.

[20] S. Yadegari, N. Kazemi, and S. Nafissi, "Clinical and electrophysiological features of Guillain-Barré syndrome in Iran," J. Clin. Neurosci., vol. 21, no. 9, pp. 1554-1557, Sep. 2014, doi: 10.1016/j.jocn.2013.11.041.

[21] et al. Gunasekera SM, "Guillain-Barre 
syndrome in Sri Lanka: subtypes and trends," Sri lanka J. Neurol., 2010, [Online]. Available: http://docplayer.net/52783819Sri-lanka-journal-of-neurology.html.

[22] G. M. McKhann et al., "Acute motor axonal neuropathy: A frequent cause of acute flaccid paralysis in China," Ann. Neurol., vol. 33, no. 4, pp. 333-342, Apr. 1993, doi: 10.1002/ana.410330402.

[23] E. Purnomo, "Nekat Tanam di Musim Pancaroba," 2017. http://bloktuban.com/2017/03/30/nekattanam-di-musim-pancaroba/ (accessed Sep. 19, 2020).

[24] A. D. Putera, “Oktober-November Masa Pancaroba, Jabodetabek Berpotensi Alami Hujan Es," 2017. https://megapolitan.kompas.com/read/2017/ 10/02/09513351/oktober-november-masapancaroba-jabodetabek-berpotensi-alamihujan-es (accessed Sep. 19, 2020).

[25] A. Suminar, "Musim Pancaroba di Jatim Antara April-Juni 2018," 2018. https://www.suarasurabaya.net/kelanakota/ 2018/Musim-Pancaroba-di-Jatim-AntaraApril-Juni-2018/.

[26] G. Joseph, "BKMG: Indonesia Mulai Masuk Musim Pancaroba pada September Hingga November," 2018. .

[27] S. humairah Utami, "BMKG Peringatkan Dua Risiko Bencana di Musim Pancaroba," 2019.

https://www.suara.com/health/2019/04/18/1 80000/bmkg-peringatkan-dua-risikobencana-di-musim-pancaroba.

[28] C. Ang, "Musim Pancaroba Sudah Dimulai pada Awal November," 2019. https://mediaindonesia.com/read/detail/269 136-musim-pancaroba-sudah-dimulai-padaawal-november\#: :text=HUJAN mulai mengguyur sebagian wilayah,mulai terjadi pada November 2019. 